\title{
Keragaan Agronomi Cabai Keriting (Capsicum annuum L.) IPB di Lahan Pasang Surut Sumatera Selatan
}

\section{Agronomic Performance of IPB's Curly Chili (Capsicum annuum L.) in Tidal Lands of South Sumatra}

\author{
Evriani Mareza $^{1}$, Karlin Agustina ${ }^{1}$, Yursida $^{1}$, dan Muhamad Syukur ${ }^{2}$ \\ 'Program Studi Agroteknologi, Fakultas Pertanian Universitas IBA \\ Jl. Mayor Ruslan, Palembang 30113, Indonesia \\ ${ }^{2}$ Departemen Agronomi dan Hortikultura, Fakultas Pertanian, Institut Pertanian Bogor \\ (IPB University), Jl. Meranti, Kampus IPB Darmaga, Bogor 16680, Indonesia
}

Diterima 16 Juni 2021/Disetujui 10 Agustus 2021

\begin{abstract}
The use of curly chili as a food ingredient continues to increase. It is necessary to increase production through the use of superior varieties by utilizing tidal land that is widely available in South Sumatra. This research aimed to obtain superior varieties of curly chili IPB with the potential to be developed for tidal land of South Sumatra. The experiment was conducted from July 2020 to January 2021 on potential acidic sulfate soil of tidal land overflow type C, using a randomized complete block design with three replications. Tested genotypes were six IPB's curly chilies, namely F10-120005-141-16-35-3-2B, F10-120005-141-16-35-1-4-3B, F10-120005-141-16-35-7-1-3B, F10-120005-241-2-9-4-4-1-1B, F10-120005-120-7-1-7-81-2B, F11-0005-9-6, and four check genotypes, namely SSP, Laris, Caman, F1-PM999. Analysis of variance followed by the HSD test was conducted. The relationship between variables was analyzed using Pearson correlation. Test genotype F10120005-120-7-1-7-8-1-2B had tall stems and produced higher fruit weight than the check genotype, as it has the highest flesh thickness, longer fruit, and the largest fruit diameter. IPB genotypes F10-120005-141-16-35-1-4-3B, F10-120005-141-1635-7-1-3B, F10-120005-241-2-9-4-4-1-1B, F10-120005-120-7-1-7-8-1-2B are potential to be developed as superior curly chili varieties in potential acidic sulfate soil on tidal land of South Sumatra, with productivity ranging from 11.38 to 12.92 ton ha ${ }^{-1}$. Curly chili genotype had different growth abilities in tidal land depending on their ability to adapt to the growing environment according to their genetic characteristics.
\end{abstract}

Keywords: adaptive genotype, check genotype, suboptimal land, test genotype

\section{ABSTRAK}

Penggunaan cabai keriting sebagai bahan makanan terus meningkat. Dibutuhkan peningkatan produksi melalui penggunaan varietas unggul dengan memanfaatkan lahan pasang surut yang banyak terdapat di Sumatera Selatan. Penelitian bertujuan mendapatkan genotipe cabai keriting IPB yang memiliki keragaan agronomi yang unggul dan berpotensi untuk dikembangkan di lahan pasang surut Sumatera Selatan. Penelitian dilaksanakan bulan Juli 2020 sampai Januari 2021 di lahan pasang surut sulfat masam potensial dengan luapan tipe $C$ menggunakan rancangan acak kelompok dengan tiga ulangan. Genotipe yang diuji adalah enam cabai keriting IPB F10-120005-141-16-35-3-2B, F10-120005-141-16-35-1-43B, F10-120005-141-16-35-7-1-3B, F10-120005-241-2-9-4-4-1-1B, F10-120005-120-7-1-7-8-1-2B, F11-0005-9-6, dan empat genotipe pembanding SSP, Laris, Caman, F1-PM999. Data dianalisis ragam dengan uji lanjut Beda Nyata Jujur. Hubungan antar peubah dianalisis korelasi Pearson. Genotipe uji F10-120005-120-7-1-7-8-1-2B memiliki batang tinggi dan menghasilan bobot per buah lebih tinggi dari genotipe pembanding, karena didukung oleh tebal daging buah tertinggi, buah yang panjang, dan diameter buah terbesar. Genotipe IPB F10-120005-141-16-35-1-4-3B, F10-120005-141-16-35-7-1-3B, F10-120005-241-2-9-4-4-1-1B, F10-120005-120-7-1-7-8-1-2B berpotensi untuk dikembangkan sebagai varietas unggul di lahan pasang surut sulfat masam potensial Sumatera Selatan, dengan produktivitas 11.38 ton ha ${ }^{-1}$ sampai 12.92 ton ha- . Genotipe cabai keriting mempunyai kemampuan tumbuh yang berbeda di lahan pasang surut, tergantung kemampuannya beradaptasi dengan lingkungan tumbuh sesuai dengan sifat genetik yang dimiliki.

Kata kunci: genotipe adaptif, genotipe pembanding, genotipe uji, lahan suboptimal

\footnotetext{
* Penulis untuk korespondensi. e-mail: karlinagustina4@gmail.com
} 


\section{PENDAHULUAN}

Cabai merupakan salah satu komoditas hortikultura unggulan yang banyak dimanfaatkan sebagai penyedap masakan, memiliki nilai ekonomi tinggi dan banyak dibudidayakan di Indonesia (Syukur et al., 2010; Dermawan et al., 2019; Juharni et al., 2020). Menurut Pusat Data dan Sistem Informasi Pertanian (2015), kebutuhan cabai untuk kota besar yang berpenduduk satu juta atau lebih sekitar 800,000 ton per tahun atau 66,000 ton per bulan. Diperlukan pasokan yang mencukupi untuk memenuhi kebutuhan cabai tersebut. Peningkatan penggunaan cabai sebagai bahan makanan sebesar $10.87 \%$ terjadi setiap tahun, dimana total penggunaan cabai sebagai bahan makanan tahun 2014 sebesar 1,925 juta ton.

Produksi cabai merah dengan tangkai pada tahun 2014, sebesar 1,075 juta ton. Sentra produksi cabai nasional terdapat di Jawa Barat, Sumatera Utara, Jawa Tengah, Jawa Timur, Sumatera Barat dan Aceh. Produksi dari Pulau Jawa $51.8 \%$ dan dari luar Jawa 48.2\%, dengan produktivitas di Pulau Jawa 9.35 ton ha-1 sedangkan di luar jawa 7.49 ton $\mathrm{ha}^{-1}$ (Pusat Data dan Sistem Informasi Pertanian, 2015).

Produktivitas cabai di Indonesia terus meningkat sejak 2010, namun demikian data Kementrian Pertanian (Kementan) tahun 2019, tingkat produktivitas cabai baru mencapai 8.77 ton ha $^{-1}$ (cabai besar dan cabai keriting) dan 7.8 ton ha-1 (cabai rawit). Hal ini masih lebih rendah dibandingkan potensi produktivitas nasional yang menurut Syukur et al. (2010) dan Qosim et al. (2013) dapat mencapai 12 ton $\mathrm{ha}^{-1}$. Oleh sebab itu perlu terus dilakukan perbaikan genetik serta sistem budidaya agar produksi cabai optimal.

Pembangunan pertanian belakangan ini mengarah kepada pemanfaatan lahan suboptimal untuk menggantikan lahan-lahan subur yang telah terkonversi untuk keperluan non pertanian. Luas lahan suboptimal di Indonesia diperkirakan mencapai 123.1 juta ha lahan kering dan 33.4 juta ha lahan rawa. Dari luas lahan rawa yang ada, 20.1 juta ha (60.2\%) merupakan lahan pasang surut dan 13.3 juta ha (39.8\%) merupakan lahan rawa lebak. Luas lahan pasang surut di Sumatera Selatan diperkirakan mencapai 1.9 juta ha, pada tahun 2008 sekitar 413,000 ha dari luasan tersebut telah direklamasi dan dimanfaatkan untuk kegiatan pertanian (Sulistiyani, 2013).

Upaya peningkatan produktivitas tanaman dapat dilakukan diantaranya melalui perakitan varietas unggul baru yang spesifik lingkungan atau yang memiliki kemampuan yang luas dalam beradaptasi dengan lingkungan (Syukur et al., 2010; Polizel et al., 2013; Widyawati et al., 2014; Rono et al., 2016; Soares et al., 2017; Yunandra, et al., 2017). Penggunaan varietas unggul diharapkan dapat meningkatkan produksi cabai sehingga dapat menjaga keseimbangan ketersediaan dan permintaan. Namun perlu diperhatikan tingkat adaptasi setiap varietas terhadap agroekosistem tempat varietas ditanam. Demikian pula di lahan pasang surut sulfat masam Sumatera Selatan, masih dibutuhkan varietas yang toleran di lahan tersebut.

Lahan pasang surut sulfat masam identik dengan lahan yang memiliki $\mathrm{pH}$ masam dengan rendahnya kandungan unsur hara dalam tanah. Rendahnya tingkat kesuburan alami tanah di lahan pasang surut berkaitan erat dengan karakteristik lahannya. Kemasaman yang tinggi $(\mathrm{pH}<4.0)$ berdampak pada meningkatnya kelarutan $\mathrm{Al}$, Fe dan $\mathrm{Mn}$. Lahan pasang surut sulfat masam sangat potensial untuk dikembangkan dibidang pertanian melalui pengelolaan dan penanganan yang tepat, termasuk untuk budidaya tanaman cabai (Koesrini dan William, 2006; Galingging, 2011). Menurut Koesrini dan William (2006), produktivitas cabai di lahan pasang surut Kalimantan Selatan baru mencapai 7.3 ton ha ${ }^{-1}$. Varietas Hot Chilli paling toleran di lahan pasang surut sulfat masam dengan pemberian kapur 2 ton ha-1.

Informasi keragaan varietas cabai keriting yang adaptif di lahan pasang surut sulfat masam potensial Sumatera Selatan masih belum tersedia. Berdasarkan hal tersebut maka dilakukan penelitian yang bertujuan untuk mendapatkan genotipe cabai keriting IPB yang memiliki keragaan agronomi yang unggul dan berpotensi untuk dikembangkan di lahan pasang surut Sumatera Selatan.

\section{BAHAN DAN METODE}

\section{Bahan Genetik yang Diuji}

Genotipe yang diuji terdiri dari enam genotipe dari IPB University berupa generasi ke-10 dan ke-11, yaitu genotipe F10-120005-141-16-35-3-2B, F10-120005-141-16-35-1-43B, F10-120005-141-16-35-7-1-3B, F10-120005-241-2-94-4-1-1B, F10-120005-120-7-1-7-8-1-2B, dan F11-0005-96. Keragaan genotipe di atas dibandingkan dengan empat varietas pembanding SSP, Laris, Caman, dan F1-PM999.

\section{Perancangan Percobaan}

Pengujian dilaksanakan dari bulan Juli 2020 sampai Februari 2021 di lahan pasang surut sulfat masam potensial dengan tipe luapan C, Desa Banyu Urip, Kecamatan Tanjung Lago, Kabupaten Banyuasin, Propinsi Sumatera Selatan. Lahan memiliki kedalaman pirit $>50 \mathrm{~cm}$ dengan jenis tanah aluvial.

Genotipe yang diuji ditanam dalam rancangan acak kelompok (RAK) dengan tiga ulangan. Ukuran plot $3 \mathrm{~m} \mathrm{x}$ $4 \mathrm{~m}$ dengan jarak tanam $60 \mathrm{~cm} \times 70 \mathrm{~cm}$. Pada setiap plot terdapat 35 tanaman dan dipilih secara acak 10 tanaman sebagai tanaman contoh.

\section{Pelaksanaan}

Teknik budidaya yang digunakan merupakan teknik budidaya standar untuk tanaman cabai. Penyemaian, menggunakan tray semai dengan media kompos, pupuk kandang dan arang sekam dengan perbandingan 1:1:1. Pengolahan tanah menggunakan hand tractor. Parit drainase dibuat di sekeliling lahan dan di pembatas ulangan untuk mengatur keluar masuk air pasang surut. Pemupukan dasar menggunakan pupuk kandang 20 ton $\mathrm{ha}^{-1}$ dan pengapuran dolomit dilakukan dua minggu sebelum pindah tanam, kemudian ditutup dengan mulsa plastik hitam. Penanaman 
setelah bibit berumur 5 minggu setelah semai (mss) dengan jarak $60 \mathrm{~cm}$ x $70 \mathrm{~cm}$. Pemeliharaan meliputi penyiraman, penyulaman, pewiwilan, dan pengajiran. Pemupukan dibagi menjadi dua, yaitu pemupukan dasar (pupuk kandang 20 ton ha-1 dicampurkan setelah selesai pengolahan tanah, dan pupuk N $120 \mathrm{~kg} \mathrm{ha}^{-1}, \mathrm{P}_{2} \mathrm{O}_{5} 80 \mathrm{~kg} \mathrm{ha}^{-1}, \mathrm{~K}_{2} \mathrm{O} 120 \mathrm{~kg} \mathrm{ha}^{-1}$ diberikan saat tanam), pemupukan susulan $\mathrm{N} 330 \mathrm{~kg} \mathrm{ha}^{-1}$ diberikan tiga kali pada saat umur 15, 35, dan 50 hari setelah tanam (hst) dan pupuk daun. Pencegahan dan pengendalian hama dan penyakit dilakukan secara kimiawi setiap minggu, sedangkan gulma dikendalikan secara manual tergantung kondisi di lahan. Panen dilakukan secara bertahap dengan interval waktu satu minggu selama 10 kali panen.

\section{Pengamatan dan Analisis Data}

Peubah yang diamati meliputi karakter vegetatif tanaman cabai (tinggi tanaman, tinggi dikotom, diameter batang, panjang daun, dan lebar daun), serta karakter generatif dan produksi cabai (umur berbunga, umur panen, tebal daging buah, panjang buah, diameter buah, bobot 1,000 biji, jumlah buah per tanaman, bobot per buah, bobot buah per tanaman, dan produktivitas). Pengamatan dilakukan sesuai dengan pedoman berdasarkan deskriptor cabai dari International Plant Genetic Recources Institute (IPGRI, 1995).

Data yang diperoleh dikompilasi dan dilakukan analisis ragam, peubah yang berbeda nyata pada taraf 5\% dilakukan uji nilai tengah Beda Nyata Jujur, untuk melihat hubungan antar peubah dengan uji korelasi Pearson. Analisis data menggunakan program Statistical Analysis System (SAS) versi 9.0 .

\section{HASIL DAN PEMBAHASAN}

Genotipe cabai keriting tumbuh baik di lahan pasang surut sulfat masam potensial Sumatera Selatan. Sekitar 5\% populasi terhambat pertumbuhaannya akibat luapan air pasang surut.

Hasil analisis ragam menunjukkan bahwa genotipe cabai keriting berpengaruh nyata terhadap tinggi tanaman, tinggi dikotom, diameter batang, tebal daging buah, panjang buah, diameter buah, bobot 1,000 biji dan bobot per buah, tetapi berpengaruh tidak nyata terhadap panjang daun, lebar daun, umur berbunga, umur panen, jumlah buah per tanaman, bobot buah per tanaman dan produktivitas tanaman cabai yang di tanaman di lahan pasang surut sulfat masam potensial Sumatera Selatan (Tabel 1).

\section{Karakter Vegetatif}

Pertumbuhan tinggi tanaman, tinggi dikotom dan diameter batang berbeda antar genotipe (Tabel 2). Genotipe uji F10-120005-120-7-1-7-8-1-2B memiliki tinggi tanaman tertinggi berbeda nyata dengan genotipe yang lain, tetapi berbeda tidak nyata dengan genotipe uji F10-120005141-16-35-1-4-3B, F10-120005-141-16-35-7-1-3B, dan genotipe pembanding Laris dan F1-PM999. Tinggi dikotom tertinggi pada genotipe pembanding Laris dan F1-PM999, dan diameter batang terbesar terdapat pada genotipe uji F10-120005-141-16-35-1-4-3B berbeda nyata dengan genotipe lain. Hal ini menunjukkan bahwa pertumbuhan tanaman cabai yang diuji memiliki keragaman berdasarkan sifat yang dimiliki oleh setiap genotipe. Pertumbuhan dan perkembangan tanaman dapat dijadikan tolak ukur respon sifat genetik yang dimiliki tanaman terhadap lingkungan tumbuh tertentu. Respon yang berbeda terhadap lingkungan tumbuh berhubungan dengan susunan genotipe yang dimiliki oleh setiap varietas yang akan menentukan ciri potensi genetik, mulai dari ciri morfologi hingga kemampuan produksi. Oleh karena itu, salah satu hal penting untuk meningkatkan produksi tanaman cabai adalah dengan menggunakan varietas unggul (Hayati, 2012; Dermawan et al., 2019; Fitria et al., 2021).

\section{Karakter Generatif dan Produksi}

Umur berbunga dan umur panen antar genotipe berbeda tidak nyata. Umur berbunga berkisar antara 82.00-84.33 hst, sedangkan umur panen berkisar antara 111.33-113.67 hari setelah tanam (hst) (Tabel 2). Untuk memperbaiki komponen produksi, maka perbaikan karakter umur berbunga yang dilakukan melalui program pemuliaan tanaman juga perlu dilakukan (Yunandra et al., 2017). Menurut Hilmayanti et al. (2006), salah satu karakter yang diinginkan dari varietas unggul tanaman cabai adalah memiliki umur berbunga dan umur panen genjah.

Tabel 1. Hasil analisis ragam terhadap pertumbuhan dan produksi genotipe cabai keriting di lahan pasang surut Sumatera Selatan

\begin{tabular}{llc}
\hline No. & Peubah yang diamati & F hitung \\
\hline 1 & Tinggi tanaman $(\mathrm{cm})$ & $3.17^{*}$ \\
2 & Tinggi dikotom $(\mathrm{cm})$ & $9.71^{*}$ \\
3 & Diameter batang $(\mathrm{cm})$ & $1.97^{*}$ \\
4 & Panjang daun $(\mathrm{cm})$ & $0.80 \mathrm{tn}$ \\
5 & Lebar daun $(\mathrm{cm})$ & $1.53 \mathrm{tn}$ \\
6 & Umur berbunga (hst) & $0.73 \mathrm{tn}$ \\
7 & Umur panen (hst) & $0.50 \mathrm{tn}$ \\
8 & Tebal daging buah (mm) & $2.49^{*}$ \\
9 & Panjang buah (cm) & $27.75^{*}$ \\
10 & Diameter buah (cm) & $12.23^{*}$ \\
11 & Bobot 1,000 biji (g) & $3.77^{*}$ \\
12 & Jumlah buah per tanaman (buah) & $2.54 \mathrm{tn}$ \\
13 & Bobot per buah (g) & $11.02^{*}$ \\
14 & Bobot buah per tanaman (g) & $1.18 \mathrm{tn}$ \\
15 & Produktivitas tanaman cabai (ton ha $\left.{ }^{-1}\right)$ & $1.18 \mathrm{tn}$ \\
\hline
\end{tabular}

Keterangan: * = berpengaruh nyata; $\mathrm{tn}=$ tidak berpengaruh nyata berdasarkan analisis ragam, $\mathrm{hst}=$ hari setelah tanam 
Tebal daging buah berbeda nyata antar genotipe cabai keriting. Genotipe uji F10-120005-120-7-1-7-81-2B memiliki daging buah yang paling tebal, berbeda nyata dengan genotipe lainnya kecuali dengan genotipe uji F10-120005-141-16-35-1-4-3B (Tabel 3). Sejalan dengan penelitian Rahayu dan Purnamaningsih (2018), hasil penelitian menunjukkan tebal daging buah berkorelasi dengan bobot per buah (Tabel 5), semakin tebal daging buah maka bobot per buah semakin berat yang akan mempengaruhi bobot buah per tanaman. Genotipe uji F10120005-141-16-35-1-4-3B dan F10-120005-120-7-1-7-8-12B yang memiliki daging buah yang tebal (Tabel 3), juga menghasilkan bobot per buah dan bobot buah per tanaman yang lebih berat (Tabel 4).

Masing-masing genotipe cabai keriting menghasilkan buah dengan panjang yang berbeda nyata. Genotipe pembanding Caman memiliki rerata panjang buahterpanjang, sedangkan buah terpendek dihasilkan oleh genotipe uji F110005-9-6 (Tabel 3). Menurut Syukur dan Rosidah (2014), karakter panjang buah cabai sangat dipengaruhi oleh faktor genetis. Berdasarkan kriteria yang ditetapkan oleh Badan Standarisasi Nasional (1998), mutu buah cabai berdasarkan panjangnya dibedakan menjadi mutu I untuk buah cabai yang memiliki panjang $12-17 \mathrm{~cm}$, mutu II untuk panjang buah 9-11 cm dan mutu III untuk buah dengan panjang $<9 \mathrm{~cm}$. Beberapa industri di Indonesia yang menggunakan cabai sebagai bahan baku mensyaratkan kualitas cabai yang digunakan dengan panjang berukuran antara 9.5-14.5 cm. Dengan demikian, genotipe uji F10-120005-141-16-35-32B, F10-120005-141-16-35-7-1-3B, dan F10-120005-1207-1-7-8-1-2B masuk di dalam kriteria mutu I untuk cabai industri.
Diameter buah paling besar terdapat pada genotipe uji F10-120005-120-7-1-7-8-1-2B, berbeda nyata dengan genotipe lainnya. Diameter buah paling kecil terdapat pada genotipe pembanding F1-PM999, berbeda tidak nyata dengan Caman dan F10-120005-141-16-35-3-2B (Tabel 3). Ukuran diameter buah berkorelasi dengan bobot per buah (Tabel 5), tercermin dari hasil penelitian yang menunjukkan genotipe uji F10-120005-120-7-1-7-8-1-2B yang memiliki diameter buah terbesar juga memiliki bobot per buah terberat (Tabel 4). Demikian pula dengan hasil penelitian Rahayu dan Purnamaningsih (2018) yang menunjukkan bahwa semakin besar diameter buah, maka bobot buah per tanaman semakin berat. Diameter buah juga merupakan salah satu kriteria yang ditetapkan oleh industri yang menggunakan cabai sebagai bahan olahan. Cabai besar masuk ke dalam kriteria mutu I jika mempunyai diameter buah $1.5-1.7 \mathrm{~cm}$, mutu II 1.3 - $1.4 \mathrm{~cm}$ dan mutu III jika diameter buah $<1.3$ cm (Badan Standarisasi Nasional, 1998).

Data pada Tabel 4 menunjukkan bahwa genotipe pembanding F1-PM999 secara tabulasi menghasilkan jumlah buah per tanaman terbanyak. Kemampuan tanaman cabai menghasilkan buah bergantung pada asimilat yang dihasilkan yang ditentukan oleh pertumbuhan selama fase vegetatif sebelum memasuki fase reproduktif. Menurut Sabaghnia et al. (2015); Yunandra et al. (2017); Juharni et al. (2020), varietas unggul akan memberikan respon yang positif terhadap lingkungan sehingga mampu memberikan hasil yang tinggi pada kondisi lingkungan yang berbeda.

Bobot buah cabai terberat dihasilkan oleh genotipe uji F10-120005-120-7-1-7-8-1-2B, sedangkan bobot per buah terendah pada genotipe pembanding Laris dan F1-PM999, berbeda nyata dengan genotipe lain (Tabel 4). Hasil

Tabel 2. Rerata tinggi tanaman, tinggi dikotom, diameter batang, panjang daun, lebar daun, umur berbunga dan umur panen genotipe cabai keriting di lahan pasang surut Sumatera Selatan

\begin{tabular}{|c|c|c|c|c|c|c|c|}
\hline Genotipe & $\begin{array}{l}\text { Tinggi } \\
\text { tanaman } \\
(\mathrm{cm})\end{array}$ & $\begin{array}{l}\text { Tinggi } \\
\text { dikotom } \\
(\mathrm{cm})\end{array}$ & $\begin{array}{c}\text { Diameter } \\
\text { batang } \\
(\mathrm{cm})\end{array}$ & $\begin{array}{c}\text { Panjang } \\
\text { daun } \\
(\mathrm{cm})\end{array}$ & $\begin{array}{l}\text { Lebar } \\
\text { daun } \\
(\mathrm{cm})\end{array}$ & $\begin{array}{c}\text { Umur } \\
\text { berbunga } \\
\text { (hst) }\end{array}$ & $\begin{array}{c}\text { Umur } \\
\text { panen } \\
(\mathrm{hst})\end{array}$ \\
\hline \multicolumn{8}{|l|}{ Genotipe uji } \\
\hline F10-120005-141-16-35-3-2B & $50.80 \mathrm{~cd}$ & $20.17 \mathrm{e}$ & $1.38 \mathrm{cde}$ & 9.44 & 3.45 & 82.0 & 113.7 \\
\hline F10-120005-141-16-35-1-4-3B & $57.90 \mathrm{abc}$ & $23.70 \mathrm{cde}$ & $2.29 \mathrm{a}$ & 9.28 & 3.29 & 82.0 & 113.7 \\
\hline F10120005-141-16-35-7-1-3B & $66.73 a$ & $23.35 \mathrm{cde}$ & $1.67 \mathrm{~b}$ & 8.89 & 3.06 & 82.0 & 111.3 \\
\hline F10-120005-241-2-9-4-4-1-1B & $49.51 \mathrm{~cd}$ & $22.69 \mathrm{cde}$ & $1.38 \mathrm{cde}$ & 9.57 & 3.17 & 82.0 & 113.7 \\
\hline F10-120005-120-7-1-7-8-1-2B & $68.02 \mathrm{a}$ & $29.29 b$ & $1.33 \mathrm{cde}$ & 14.99 & 4.15 & 82.0 & 111.3 \\
\hline F11-0005-9-6 & $42.12 d$ & 21.46de & $1.13 \mathrm{e}$ & 9.62 & 3.57 & 84.3 & 113.7 \\
\hline \multicolumn{8}{|l|}{ Genotipe pembanding } \\
\hline SSP & $53.00 \mathrm{bcd}$ & $25.35 \mathrm{c}$ & $1.31 \mathrm{cde}$ & 8.88 & 3.09 & 84.3 & 111.3 \\
\hline Laris & $63.12 \mathrm{ab}$ & $33.60 \mathrm{a}$ & $1.53 b c$ & 9.69 & 3.46 & 84.3 & 111.3 \\
\hline Caman & $53.52 b c$ & $25.13 \mathrm{~cd}$ & $1.23 \mathrm{de}$ & 9.23 & 3.08 & 84.3 & 111.3 \\
\hline F1-PM999 & $59.82 \mathrm{abc}$ & $33.20 \mathrm{a}$ & $1.49 \mathrm{bcd}$ & 10.87 & 3.45 & 82.0 & 111.3 \\
\hline
\end{tabular}

Keterangan: Angka rerata yang diikuti oleh huruf yang sama pada kolom yang sama tidak berbeda nyata berdasarkan uji BNJ taraf 5\% 
Tabel 3. Rerata tebal daging buah, panjang buah, diameter buah, dan bobot 1,000 biji genotipe cabai keriting di lahan pasang surut Sumatera Selatan

\begin{tabular}{lcccc}
\hline Genotipe & $\begin{array}{c}\text { Tebal daging buah } \\
(\mathrm{mm})\end{array}$ & $\begin{array}{c}\text { Panjang buah } \\
(\mathrm{cm})\end{array}$ & $\begin{array}{c}\text { Diameter buah } \\
(\mathrm{cm})\end{array}$ & $\begin{array}{c}\text { Bobot 1,000 biji } \\
(\mathrm{g})\end{array}$ \\
\hline Genotipe uji & & & & \\
F10-120005-141-16-35-3-2B & $1.09 \mathrm{~cd}$ & $12.37 \mathrm{~b}$ & $0.79 \mathrm{de}$ & $8.90 \mathrm{abc}$ \\
F10-120005-141-16-35-1-4-3B & $1.44 \mathrm{ab}$ & $11.28 \mathrm{bc}$ & $0.86 \mathrm{~cd}$ & $9.27 \mathrm{ab}$ \\
F10120005-141-16-35-7-1-3B & $1.27 \mathrm{bc}$ & $12.16 \mathrm{bc}$ & $0.91 \mathrm{c}$ & $9.27 \mathrm{ab}$ \\
F10-120005-241-2-9-4-4-1-1B & $1.32 \mathrm{bc}$ & $11.75 \mathrm{bc}$ & $0.87 \mathrm{~cd}$ & $7.37 \mathrm{cde}$ \\
F10-120005-120-7-1-7-8-1-2B & $1.63 \mathrm{a}$ & $12.29 \mathrm{bc}$ & $1.16 \mathrm{a}$ & $7.37 \mathrm{cde}$ \\
F11-0005-9-6 & $1.12 \mathrm{~cd}$ & $7.32 \mathrm{e}$ & $1.05 \mathrm{~b}$ & $7.63 \mathrm{bcd}$ \\
Genotipe pembanding & & & & \\
SSP & $1.17 \mathrm{bcd}$ & $11.16 \mathrm{c}$ & $0.83 \mathrm{~cd}$ & $9.80 \mathrm{a}$ \\
Laris & $1.2 \mathrm{bcd}$ & $9.03 \mathrm{~d}$ & $0.84 \mathrm{~cd}$ & $5.90 \mathrm{e}$ \\
Caman & $1.23 \mathrm{bcd}$ & $16.42 \mathrm{a}$ & $0.78 \mathrm{de}$ & $8.40 \mathrm{abc}$ \\
F1-PM999 & $0.97 \mathrm{~d}$ & $9.05 \mathrm{~d}$ & $0.70 \mathrm{e}$ & $6.20 \mathrm{de}$ \\
\hline
\end{tabular}

Keterangan: Angka rerata yang diikuti oleh huruf yang sama pada kolom yang sama tidak berbeda nyata berdasarkan uji BNJ taraf 5\%

penelitian menunjukkan bahwa bobot per buah berkorelasi dengan tebal daging, panjang buah, dan diameter buah (Tabel 5). Genotipe uji F10-120005-120-7-1-7-8-1-2B yang mempunyai buah dengan tebal daging tertinggi, buah yang panjang, dan diameter buah terbesar menghasilkan bobot per buah tertinggi. Bobot per buah terendah pada genotipe pembanding Laris dan F1-PM999, selain dipengaruhi oleh faktor genetik juga berhubungan dengan jumlah buah per tanaman yang banyak. Sebagaimana Rahayu dan Purnamaningsih (2018), bahwa peningkatan jumlah buah per tanaman dapat menyebabkan pertumbuhan dan perkembangan buah menjadi lebih kecil.

Berdasarkan data rerata pada Tabel 4, genotipe uji F10-120005-141-16-35-1-4-3B, F10-120005-141-16-35-71-3B, F10-120005-241-2-9-4-4-1-1B dan F10-120005-1207-1-7-8-1-2B memiliki bobot buah per tanaman yang secara tabulasi lebih tinggi dibanding genotipe pembanding. Bobot buah per tanaman berkorelasi dengan panjang buah, jumlah buah per tanaman dan bobot per buah (Tabel 5). Bobot buah per tanaman yang secara tabulasi lebih tinggi pada keempat

Tabel 4. Rerata jumlah buah per tanaman, bobot per buah, bobot buah per tanaman dan produktivitas genotipe cabai keriting di lahan pasang surut Sumatera Selatan

\begin{tabular}{lcccc}
\hline Genotipe & $\begin{array}{c}\text { Jumlah buah per } \\
\text { tanaman (buah) }\end{array}$ & $\begin{array}{c}\text { Bobot per buah } \\
(\mathrm{g})\end{array}$ & $\begin{array}{c}\text { Bobot buah } \\
\text { per tanaman }(\mathrm{g})\end{array}$ & $\begin{array}{c}\text { Produktivitas } \\
\left(\text { ton ha }{ }^{-1}\right)\end{array}$ \\
\hline Genotipe uji & & & & \\
F10-120005-141-16-35-3-2B & 210.2 & $4.26 \mathrm{~b}$ & 593.32 & 9.49 \\
F10-120005-141-16-35-1-4-3B & 226.2 & $4.24 \mathrm{~b}$ & 733.79 & 11.74 \\
F10120005-141-16-35-7-1-3B & 245.5 & $4.65 \mathrm{~b}$ & 807.73 & 12.92 \\
F10-120005-241-2-9-4-4-1-1B & 206.7 & $4.00 \mathrm{~b}$ & 710.97 & 11.38 \\
F10-120005-120-7-1-7-8-1-2B & 188.6 & $5.89 \mathrm{a}$ & 794.45 & 12.71 \\
F11-0005-9-6 & 110.9 & $4.06 \mathrm{~b}$ & 351.83 & 5.63 \\
Genotipe pembanding & & & & \\
SSP & 233.5 & $4.24 \mathrm{~b}$ & 665.07 & 10.64 \\
Laris & 273.9 & $3.00 \mathrm{c}$ & 569.79 & 9.12 \\
Caman & 177.7 & $4.49 \mathrm{~b}$ & 566.50 & 9.06 \\
F1-PM999 & 314.0 & $2.66 \mathrm{c}$ & 625.39 & 10.01 \\
\hline
\end{tabular}

Keterangan: Angka rerata yang diikuti oleh huruf yang sama pada kolom yang sama tidak berbeda nyata berdasarkan uji BNJ taraf 5\% 
genotipe uji karena didukung oleh buah yang panjang, jumlah buah per tanaman dan bobot per buah yang tinggi. Hal ini sejalan dengan hasil penelitian Murniati et al. (2013) dan Rofidah et al. (2018), semakin banyak jumlah buah per tanaman dan semakin berat bobot per buah yang dihasilkan, maka bobot buah per tanaman semakin berat. Genotipe uji F11-0005-9-6 yang secara tabulasi menghasilkan bobot buah per tanaman terendah karena jumlah buah yang dihasilkan paling sedikit.

Jumlah populasi tanaman per hektar dengan jarak tanam $60 \mathrm{~cm} \times 70 \mathrm{~cm}$ adalah 23,800 tanaman. Jika asumsi hanya $70 \%$ tanaman yang dapat tumbuh dengan baik di lahan pasang surut, maka produktivitas yang dihasilkan oleh varietas cabai keriting yang diuji berkisar antara 5.63-12.92 ton ha $^{-1}$ (Tabel 4). Produktivitas cabai keriting berkorelasi dengan bobot buah per tanaman yang dipengaruhi oleh panjang buah, jumlah buah per tanaman dan bobot per buah (Tabel 5). Genotipe uji F10-120005-141-16-35-1-4-3B, F10120005-141-16-35-7-1-3B, F10-120005-241-2-9-4-4-1-1B, dan F10-120005-120-7-1-7-8-1-2B memiliki produktivitas masing-masing 11.74 ton ha-1, 12.92 ton $\mathrm{ha}^{-1}, 11.38$ ton $\mathrm{ha}^{-1}$, dan 12.71 ton $\mathrm{ha}^{-1}$, secara tabulasi lebih tinggi dibandingkan genotipe pembanding yang memiliki produktivitas antara 9.06-10.64 ton ha ${ }^{-1}$ (Tabel 4). Produktivitas keempat genotipe uji di lahan pasang surut sulfat masam potensial Sumatera Selatan ini lebih tinggi jika dibandingkan cabai nasional 8.77 ton ha $^{-1}$ (Kementrian Pertanian, 2019). Produktivitas keempat genotipe uji tergolong tinggi, karena menurut Syukur et al. (2010) produktivitas tanaman cabai dapat mencapai 12 ton ha $^{-1}$ apabila petani menggunakan benih unggul dan menerapkan sistem budidaya tanaman yang intensif. Akan tetapi, produktivitas masih tergolong rendah jika dibandingkan potensi produktivitas cabai hibrida 20-30 ton $\mathrm{ha}^{-1}$ yang dapat dicapai jika bobot buah cabai $1 \mathrm{~kg}$ per tanaman.

Pertumbuhan tanaman cabai sangat ditentukan oleh kemampuannya beradaptasi dengan lingkungan tumbuh sesuai dengan sifat genetik yang dimiliki, dimana setiap genotipe mempunyai kemampuan tumbuh yang berbeda pada saat ditanam di lahan pasang surut sulfat masam potensial Sumatera Selatan. Menurut Zuhry et al. (2012); Dalimunthe et al. (2016); Fitria et al. (2021), pertumbuhan tanaman dan komponen produksi yang dihasilkan merupakan hasil kuantitatif yang didapatkan sebagai ekspresi faktor genetik dan respon tanaman terhadap kondisi lingkungan tempat tumbuh. Kemampuan produksi ditentukan oleh pertumbuhan selama fase vegetatif sebelum memasuki fase generatif.

Tabel 5. Hasil uji korelasi terhadap pertumbuhan dan produksi genotipe cabai keriting di lahan pasang surut Sumatera Selatan

\begin{tabular}{lcccccccccccccc}
\hline & TT & TD & DB & PD & LD & UB & UP & TDB & PB & DBh & JB & B/B & BB/T & P \\
\hline TT & 1.00 & 0.60 & 0.39 & 0.47 & -0.37 & $0.67^{*}$ & $0.67^{*}$ & 0.45 & 0.17 & 0.13 & 0.58 & 0.20 & $0.72^{*}$ & $0.72^{*}$ \\
TD & & 1.00 & 0.33 & 0.43 & 0.33 & 0.11 & $-0.69^{*}$ & -0.04 & -0.25 & -0.14 & $0.65^{*}$ & -0.41 & 0.11 & 0.11 \\
DB & & & 1.00 & -0.17 & -0.18 & -0.46 & 0.19 & 0.31 & -0.02 & -0.18 & 0.41 & -0.09 & 0.49 & 0.49 \\
PD & & & 1.00 & $0.89^{*}$ & -0.33 & -0.27 & 0.56 & -0.01 & 0.61 & -0.06 & 0.47 & 0.30 & 0.30 \\
LD & & & & 1.00 & -0.20 & -0.02 & 0.40 & -0.29 & $0.66^{*}$ & -0.20 & 0.33 & -0.02 & -0.02 \\
UB & & & & & 1.00 & -0.25 & -0.29 & -0.10 & -0.03 & -0.31 & -0.2 & -0.66 & -0.66 \\
UP & & & & & & 1.00 & -0.01 & -0.21 & 0.09 & -0.47 & -0.01 & -0.28 & -0.28 \\
TDB & & & & & & & 1.00 & 0.34 & $0.67^{*}$ & -0.27 & $0.76^{*}$ & 0.61 & 0.61 \\
PB & & & & & & & & 1.00 & 0.30 & 0.06 & $0.64^{*}$ & $0.67^{*}$ & $0.67^{*}$ \\
DBh & & & & & & & & & 1.00 & -0.49 & $0.84^{*}$ & 0.23 & 0.23 \\
JB & & & & & & & & & & 1.00 & $-0.48^{*}$ & $0.47^{*}$ & $0.47^{*}$ \\
B/B & & & & & & & & & & & 1.00 & $0.37^{*}$ & $0.37^{*}$ \\
BB/T & & & & & & & & & & & & 1.00 & $1.00^{*}$ \\
P & & & & & & & & & & & & & 1.00 \\
\hline
\end{tabular}

Keterangan: $\mathrm{TT}=$ tinggi tanaman; $\mathrm{TD}=$ tinggi dikotom; $\mathrm{DB}=$ diameter batang; $\mathrm{PD}=$ panjang daun; $\mathrm{LD}=$ lebar daun; $\mathrm{UB}=$ umur berbunga; $\mathrm{UP}=$ umur panen; $\mathrm{TDB}=$ tebal daging buah; $\mathrm{PB}=$ panjang buah; $\mathrm{DBh}=$ diameter buah; $\mathrm{JB}=$ jumlah buah; $\mathrm{B} / \mathrm{B}=$ bobot per buah; $\mathrm{BB} / \mathrm{T}=$ bobot buah per tanaman; $\mathrm{P}=$ produktivitas; * = nyata

\section{KESIMPULAN}

Genotipe uji F10-120005-120-7-1-7-8-1-2B memiliki batang tinggi dan menghasilan bobot per buah lebih tinggi dari genotipe pembanding, karena didukung oleh tebal daging buah tertinggi, buah yang panjang, dan diameter buah terbesar. Genotipe IPB F10-120005-141-16-35-1-43B, F10-120005-141-16-35-7-1-3B, F10-120005-241-2-94-4-1-1B, dan F10-120005-120-7-1-7-8-1-2B berpotensi untuk dikembangkan sebagai varietas unggul di lahan pasang surut sulfat masam potensial Sumatera Selatan, dengan produktivitas 11.38 ton ha- sampai 12.92 ton $\mathrm{ha}^{-1}$. 


\section{UCAPAN TERIMA KASIH}

Ucapan terima kasih disampaikan kepada Kementerian Riset dan Teknologi/Badan Riset Inovasi Nasional yang telah membiayai penelitian ini melalui dana Prioritas Riset Nasional Tahun 2020 serta Konsorsium Cabai IPB University.

\section{DAFTAR PUSTAKA}

Badan Standardisasi Nasional. 1998. Standar Nasional Indonesia Cabai Merah Segar, SNI No. 01-4481998 .

Dalimunthe, M.B., Azwana, E.L. Panggabean. 2016. Pertumbuhan dan produksi tanaman cabai (Capsicum annum L.) terhadap pemberian pupuk organik pada berbagai media tanam. Agrotekma. 1:1-11.

Dermawan, R., M. Farid, I.R. Saleh, R. Syarifuddin. 2019. Respon tanaman cabai besar (Capsicum annuum L.) terhadap pengayaan Trichoderma pada media tanam dan aplikasi pupuk boron. J. Hort. Indonesia 10:1-9.

Fitria, E., E. Kesumawaty, B. Basyah, Asis. 2021. Peran Trichoderma harzianum sebagai penghasil zat pengatur tumbuh terhadap pertumbuhan dan produktivitas varietas cabai (Capsicum annuиm L.). J. Agron. Indonesia 49:45-52.

Galingging, R.Y. 2011. Evaluasi pertumbuhan 15 aksesi cabai dataran rendah di lahan pasang surut Kalimantan Tengah. Agripura 7:937-941.

Hayati, E., T. Mahmud, R. Fazil. 2012. Pengaruh jenis pupuk organik dan varietas terhadap pertumbuhan dan hasil tanaman cabai (Capsicum annum L.). J. Floratek 7: 173-181.

Hilmayanti I., W. Dewi, Murdaningsih, M. Rahardja, N. Rostini, R. Setiamihardja. 2006. Pewarisan karakter umur berbunga dan ukuran buah cabai merah (Capsicum annuum L.). Zuriat 17:86-93.

International Plant Genetic Resources Institute. 1995. Annual Report 1995-Biodiversity International, Rome, IT.

Juharni, M. Syukur, W.B. Suwarno, A. Maharijaya. 2020. Analisis stabilitas parametrik hasil cabai rawit (Capsicum fructescens L.) pada empat lokasi dataran rendah. J. Agron. Indonesia 48:258-267.

Koesrini, E. William. 2006. Pengaruh pemberian amelioran terhadap pertumbuhan dan hasil cabai merah (Capsicum annum) di lahan sulfat masam. Bul. Agron. 34:153-159.
Murniati, N.S., Setyono, A.A. Sjarif. 2013. Analisis korelasi dan sidik lintas peubah pertumbuhan terhadap produksi cabai merah (Capsicum annum L.). J. Pertanian 3:111-122.

Polizel, A.C., F.C. Juliatti, O.T. Hamawaki, R.L. Hamawaki, S.L. Guimarães. 2013. Phenotypical adaptability and stability of soybean genotypes in the state of Mato Grosso. Bioscience J. 29:910-920.

Pusat Data dan Sistem Informasi Pertanian, 2015. Outlook Komoditas Pertanian Subsektor Hortikultura: Cabai. Kementrian Pertanian Republik Indonesia, Jakarta.

Qosim,W.A., M., Rachmadi, J.S. Hamdani, I. Nuri. 2013. Penampilan fenotipik, variabilitas, dan heritabilitas 32 genotipe cabai merah berdaya hasil tinggi. J. Agron. Indonesia 41:140-146.

Rahayu, F.C., S.L. Purnamaningsih. 2018. Uji daya hasil pendahuluan enam galur cabai rawit (Capsicum frustesnens). J. Produksi Tanaman 6:386-391.

Rofidah, N.M., I. Yulianah, Respatijarti. 2018. Korelasi antara komponen hasil dengan hasil pada populasi F6 tanaman cabai merah besar (Capsicum annum L.). J. Produksi Tanaman 6:230-235.

Rono, J.K., E.K. Cheruiyot, J.O. Othira, V.W. Njuguna, J.K. Macharia, J. Owuoche, M. Oyier, A.M. Kange. 2016. Adaptability and stability study of selected sweet sorghum genotypes for ethanol production under different environments using AMMI analysis and GGE-biplots. Sci. World J. 5:1-14.

Sabaghnia, N., R. Karimizadeh, M. Mohammadi. 2015. Graphic analysis of yield stability in new improved lentil (Lens culinaris Medik.) genotypes using nonparametric statistics. Acta Agric. Slovenica. 103:113-127.

Soares, I.O., A.T. Bruzi, E.V. Zambiazzi, S.R. Guilherme, M.C. Bianchi, K.B. Silva, V. Fronza, C.M. Teixeira. 2017. Stability and adaptability of soybean cultivars in Minas Gerais. Genet. Mol. Res. 16:1-7.

Sulistiyani, D.P. 2013. Evaluasi kesesuaian sifat fisik tanah pada tanaman padi (Oryza sativa L.) di lahan pasang surut Desa Telang Karya Deltaelta Telang I (P8-12S), Kecamatan Muara Telang Kabupaten Banyuasin. hal. 77-87. Dalam Herlinda, S., B. Lakitan, Sobir, Koesnandar, Suwandi, Puspitahati, M.I. Syafutri, D. Meidalima (Eds.). Prosiding Seminar Nasional Lahan Suboptimal. Palembang 20-21 September 2013. Palembang: Pusat Unggulan Riset Pengembangan Lahan Sub Optimal (PUR-PLSO) Universitas Sriwijaya. 
Syukur, M., S. Sujiprihati, R. Yunianti, D.A. Kusumah. 2010. Evaluasi daya hasil cabai hibrida dan daya adaptasinya di empat lokasi dalam dua tahun. J. Agron. Indonesia 38:43-51.

Syukur, M., S. Rosidah. 2014. Estimation of Genetic Parameter for Quantitative Characters of Pepper (Capsicum annuum L.). J. Trop. Crop Sci. 1:1-7.

Widyawati, Z., I. Yulianah, Respatijarti. 2014. Heritabilitas dan kemajuan genetik harapan populasi F2 pada tanaman cabai besar (Capsicum annuum L.). J. Produksi Tanaman 2:247-252.

Yunandra, M. Syukur, A. Maharijaya. 2017. Seleksi dan kemajuan seleksi karakter komponen hasil pada persilangan cabai keriting dan cabai besar. J. Agron. Indonesia 45:169-174.

Zuhry, E., Deviona, M. Syukur, S. Sujiprihati, Telphy. 2012. Uji daya hasil beberapa genotipe cabai (Capsicum annuum L.) toleran pada lahan gambut. J. Agroteknologi Tropika 1:1-7. 